\title{
BEHAVIOUR OF L. MONOCYTOGENES IN SLICED, VACUUM-PACKED MORTADELLA
}

\author{
Luciano dos Santos Bersot ${ }^{1 *}$; Cíntia Gillio ${ }^{1}$; Paula Tavolaro ${ }^{1}$; Mariza Landgraf ${ }^{1}$; \\ Bernadette Dora Gombossy de Melo Franco ${ }^{1}$; Maria Teresa Destro ${ }^{1}$
}

\author{
${ }^{1}$ Departamento de Alimentos e Nutrição Experimental, Faculdade de Ciências Farmacêuticas, Universidade de São Paulo, \\ São Paulo, SP, Brasil.
}

Submitted: October 11, 2006; Returned to authors for corrections: April 20, 2007; Approved: August 11, 2008.

\begin{abstract}
This study evaluated the growth of naturally occurring L. monocytogenes in sliced, vacuum-packed mortadella samples during storage at $5^{\circ} \mathrm{C}$ until the expiration date. Tukey's test indicated that counts of $L$. monocytogenes on $0,10,20,30$ and 40 days of storage were significantly different $(p<0.05)$, indicating growth during shelf life. In three trials, the mean increase was $1.72 \mathrm{log}$ cycles. Vacuum packing and storage under refrigeration were not effective in controlling the growth of L. monocytogenes in sliced mortadella, indicating that good manufacturing practices and implemented HACCP programs are essential to assure safety of this product.
\end{abstract}

Key-words: Listeria monocytogenes; growth; sliced mortadella; vacuum-packing

Listeria monocytogenes is ubiquitous and almost all kinds of foods may be contaminated with this bacterium. Equipment and utensils used in the food industry are considered important sources of contamination, and it is generally accepted that total elimination of L. monocytogenes from all foods is impracticable and may even be impossible. An important characteristic of $L$. monocytogenes is the capability to survive and grow under refrigeration, which is usually an obstacle for the growth of most foodborne pathogens. This fact is extremely relevant, mainly when ready-to-eat (RTE) products are considered, as they may have not been submitted to a listericidal step during processing and/or may have been contaminated after processing. When present, growth of Listeria may be favored by refrigeration in detriment of other microorganisms $(10,12,13)$

Epidemiological evidences indicate that food products that present the greatest risk for listeriosis dissemination are those that support the growth of the pathogen, have long shelf-life under refrigeration and are ready-to-eat $(9,18)$.

In general, contamination of meat products occurs as primary contamination of the meat but also via ingredients and environment (3). A previous study has shown that $L$. monocytogenes does not survive the cooking process of mortadella (1) indicating that presence of the pathogen in vacuum-packed sliced product is due to cross-contamination during slicing/packaging.

Information on L. monocytogenes behavior in RTE products is important for the development of new strategies to control this pathogen in the product. Thus, the objective of the present study was to evaluate the capability of naturally occurring $L$. monocytogenes to grow in sliced, vacuum-packed mortadella stored under refrigeration.

Sliced, vacuum packed mortadella samples were obtained from a meat industry in packs of $250 \mathrm{~g}$ on the day of packaging. This industry received the mortadella in pieces of $5 \mathrm{~kg}$ in the original casing from another meat plant and sliced and packed the product using a fully automatized procedure. According to the label, the shelf life of the sliced product was 40 days under refrigeration, without specifying the temperature. The samples were placed in isothermal containers, transported to the laboratory and were tested immediately (day zero) or stored at $5^{\circ} \mathrm{C}$.

Quantification of $L$. monocytogenes was done on days zero, 10, 20,30 and 40, using the method described by Farber et al. (6) in a Most Probable Number technique format (14). In each sampling day, three packs of $250 \mathrm{~g}$ were analyzed. Fifty grams of mortadella were asseptically removed from each package and

*Corresponding Author. Mailing address: UFPR, Campus Palotina, Rua Pioneiro, 2153, Jardim Dallas, Palotina, PR, 85.950-000, Palotina, PR, Brasil. Fax: (+5544) 3649-6616. E-mail: lucianobersot@ufpr.br 
transferred to plastic bags containing $450 \mathrm{~mL}$ of Listeria Enrichment Broth, UVM Formulation (LEB) (Oxoid, England). After homogenization, the mixture was submitted to four decimal dilutions (equivalent to $10 \mathrm{~g}, 1 \mathrm{~g}, 0.1 \mathrm{~g}$ and $0.01 \mathrm{~g}$ of product) in $\mathrm{LEB}$, in triplicates, and incubated at $30^{\circ} \mathrm{C}$ for $24 \mathrm{~h}$. For identification of $L$. monocytogenes, the methodology of Farber et al. (6) was carried out. The experiments were run three times (trials A, B and C).

Results were submitted to variance analysis and Tukey's test, using Statistic for Windows, release 5.0 (Stat Soft Inc, 1984-1995).

Table 1 shows the mean populations of $L$. monocytogenes $\left(\mathrm{MPNg}^{-1}\right)$ in the sliced, vacuum-packed mortadella samples, in the three trials, and the mean counts for each of the five days of analysis (days $0,10,20,30$ and 40 ). Final populations at the end of the shelf life were 89.1, 23.4 and 102.3 MPN.g ${ }^{-1}$ for trials A, B and $\mathrm{C}$, respectively. Variance analysis of the results indicated that differences in these populations were not significant ( $>0.05$ ). Tukey's test, applied to the general means, showed that differences in populations on day 10 compared to day 0 , on day 20 compared to day 10 , on day 20 compared to day 30 and on day 40 compared to day 30 were significant $(\mathrm{p}<0.05)$, indicating multiplication of $L$. monocytogenes during the shelf life of the product stored under refrigeration $\left(5^{\circ} \mathrm{C}\right)$.

Similar populations of $L$. monocytogenes at the end of shelf life were reported elsewhere. Examining sliced vacuum-packed frankfurters the authors found counts around 100-200 CFU. $\mathrm{g}^{-1}$ of the product $(16,17)$.

It is interesting to note that in two out of three trials the population of $L$. monocytogenes on the $30^{\text {th }}$ day of storage was lower than that observed on the $20^{\text {th }}$ day. This decrease in $L$. monocytogenes population may be explained by the presence of autoctonous lactic acid bacteria (LAB), well-known for their capability of inhibiting growth of L. monocytogenes during food

Table 1. Mean populations of L. monocytogenes in sliced, vacuum-packed mortadella, during storage under refrigeration for 40 days.

\begin{tabular}{ccccc}
\hline & \multicolumn{2}{c}{$\begin{array}{c}\text { Mean population } \\
(\text { MPN.g })^{-1}\end{array}$} & $\begin{array}{c}\text { General mean } \\
\text { population** }\end{array}$ \\
\hline Day & Trial A & Trial B & Trial C & $\left(\right.$ MPN.g $\left.{ }^{-1}\right)$ \\
\hline 0 & 0.03 & 1.00 & 0.25 & $0.40^{\mathrm{a} * * *}$ \\
10 & 0.14 & 0.72 & 11.20 & $4.00^{\mathrm{a}}$ \\
20 & 95.50 & 0.50 & 41.70 & $45.90^{\mathrm{b}}$ \\
30 & 12.60 & 1.60 & 2.40 & $5.50^{\mathrm{a}}$ \\
40 & 89.10 & 23.40 & 102.30 & $71.6^{\mathrm{b}}$ \\
\hline
\end{tabular}

* mean of three determinations

**mean of trials A, B and C

$* * *$ same letters indicate values that are statistically similar $(\mathrm{p}>0.05)$ storage (4). Contamination with LAB can occur during slicing and packaging procedures, mainly when hygiene conditions are precarious.

Table 2 shows that $L$. monocytogenes population increase (mean MPN. ${ }^{-1}$ ) during storage at $5^{\circ} \mathrm{C}$ for 40 days was equal to 76.4, 22.1 and 89.0 for trials A, B and C, respectively. General mean increase of L. monocytogenes was $62.5 \mathrm{MPN}$. $\mathrm{g}^{-1}$. According to several reports, L. monocytogenes population can increase up to 6 logs in vacuum-packed meat products stored under refrigeration $(3,7,8,11,17)$. However these studies were conducted with spiked products and the conditions required for the growth of microorganisms are not necessarily the same as for naturally contaminated foodstuffs. In artificially contaminated products, the microbial cells are in optimal physiological conditions, favoring the competition with the normal microbiota of the product.

Refrigeration between 4 and $8^{\circ} \mathrm{C}$ of sliced, vacuum-packed meat products does not seem to be an obstacle to $L$. monocytogenes growth, as observed in the present study and also by Rosso et al. (15). Temperatures below $2^{\circ} \mathrm{C}$ are recommended for the control of L. monocytogenes in these products; however, these temperatures are not commonly achieved at retail level. It should be also taken into account that L. monocytogenes tolerates low $\mathrm{O}_{2}$ tension, being able to survive and grow in anaerobic conditions, even at low temperatures (13), as encountered in vacuum-packed mortadella stored under refrigeration.

The low initial L. monocytogenes population in the products found in this study has also been observed by other authors $(5,16,17)$. However, these low initial numbers are not an assurance of low risk for the product since the pathogen may grow and reach risky levels $\left(\geq 100 \mathrm{~g}^{-1}\right)(13)$.

The method employed for enumeration of $L$. monocytogenes in a food product has strong influence in the results (2). Once

Table 2. Increment in population of L. monocytogenes in sliced, vacuum-packed mortadella during storage under refrigeration for 40 days

\begin{tabular}{ccccc}
\hline $\begin{array}{c}\text { Interval } \\
\text { in days }\end{array}$ & \multicolumn{3}{c}{ Increment $\left(\mathrm{MPN} . \mathrm{g}^{-1}\right)^{*}$} & $\begin{array}{c}\text { General } \\
\text { increment }\end{array}$ \\
\hline & Trial A & Trial B & Trial C & $\left(\right.$ MPN.g $\left.^{-1}\right)$ \\
\hline $0-10$ & 0.10 & -0.28 & 10.95 & 3.60 \\
$10-20$ & 95.4 & -0.22 & 30.50 & 41.9 \\
$20-30$ & -82.9 & 1.10 & -39.3 & -40.4 \\
$30-40$ & 76.5 & 21.8 & 99.9 & 66.1 \\
\hline $\begin{array}{c}\text { Total } \\
\text { increment }\end{array}$ & 76.4 & 22.1 & 89.0 & 62.5 \\
\hline
\end{tabular}

*mean of three determinations. 
initial population of the pathogen can be as low as 0.03 MPN $\mathrm{g}^{-1}$ (Table 1), one may not find L. monocytogenes in the product if the method lacks sensitivity.

In the present study L. monocytogenes was found in all sliced mortadella samples. This result differs from the one observed in a previous study (1), carried out with non-sliced mortadella, where the pathogen was detected in $26.7 \%$ of the samples. These findings indicate that slicing has an important role in the contamination process.

In view of the fact that $L$. monocytogenes can reach risky levels in vacuum-packed sliced mortadella stored under refrigeration, appropriate control measures are needed to minimize contamination of the product and/or inhibit the growth of the pathogen. Implementation of good hygiene practices (GHP), SSOPs and good manufacturing practices (GMP), together with HACCP is of uppermost importance to minimize environmental and product contamination. Reduction of shelf life, reformulation of the product by adding inhibitory ingredients, post-packing listericidal treatment (e.g. irradiation or ultra-high pressure) and active packaging are some options for the control growth of the pathogen in sliced meat products such as mortadella.

\section{ACKNOWLEDGEMENTS}

The authors would like to thank Fundação de Amparo à Pesquisa do Estado de São Paulo, FAPESP, for first author's fellowship and for project grant.

\section{RESUMO}

\section{Comportamento de L. monocytogenes em mortadelas fatiadas e embaladas a vácuo}

O presente trabalho avaliou a multiplicação de $L$. monocytogenes naturalmente presente em mortadelas fatiadas, embaladas a vácuo e estocadas a $5^{\circ} \mathrm{C}$ durante sua vida de prateleira. $\mathrm{O}$ teste Tukey indicou que as populações de $L$. monocytogenes nos tempos 10, 20, 30 e 40 dias diferiram significativamente $(p<0,05)$ indicando multiplicação durante $o$ armazenamento. Em três repetições, o aumento médio foi de 1,80 ciclos log. A embalagem a vácuo e estocagem sob refrigeração não foram suficientes para o controle da multiplicação de L. monocytogenes em mortadelas fatiadas, indicando que as boas práticas de fabricação e um sistema HACCP implantado são fundamentais para assegurar a segurança desse produto.

Palavras-chave: Listeria monocytogenes; mortadela fatiada; embalagem a vácuo.

\section{REFERENCES}

1. Bersot, L.S.; Landgraf, M.; Franco, B.D.G.M.; Destro, M.T. (2001). Production of mortadella: behavior of Listeria monocytogenes during process and storage conditions. Meat Sci., 57: 13-17.

2. Donnelly, C.W.; Nyachuba, D.G. (2006). Conventional methods for detection of Listeria. In: Ryser, E.T., Marth, E.H. (eds) Listeria, Listeriosis and Food Safety CRC Press, p. 215-256.

3. Duffy, L.L.; Vanderlinde, P.B.; Grau, F.H. (1994). Growth of Listeria monocytogenes on vacuum-packed cooked meats: effects of $\mathrm{pH}, \mathrm{a}_{\mathrm{w}}$, nitrite and ascorbate. Int. J. Food Microbiol., 23: 377-390.

4. Farber, J.; Pagotto, F.; Scherf, C. (2006). Incidence and behavior of Listeria monocytogenes in meat products. In: Ryser, E.T., Marth, E.H. (eds) Listeria, Listeriosis and Food Safety CRC Press, p. 503570 .

5. Farber, J.M.; Daley, E. (1994). Presence and growth of Listeria monocytogenes in naturally-contaminated meats. Int. J. Food Microbiol., 22: 33-42.

6. Farber, J.M.; Warburton, D.W.; Babiuk, T. (1994). Isolation of Listeria monocytogenes from all food and environmental samples. In: Canada. Health and Welfare. Compendium of analytical methods: laboratory procedures of microbiological analysis of foods. Ottawa, Polyscience, v. 3, 16 p. [MFHPB30].

7. Glass, K.A.; Doyle, M.P. (1989). Fate of Listeria monocytogenes in processed meat products during refrigerated storage. Appl. Environment. Microbiol., 55: 1565-1569.

8. Guang-Hua, W.; Mao-Zhan, S. (1997). The behaviour of Listeria monocytogenes in vacuum-packed sliced chinese spiced beef. Fleischwirtsch., 77: 57-58.

9. ILSI Research Foudantion (2005). Achieving continuous improvement in reductions in foodborne listeriosis - a risk-based approach. $J$. Food Prot., 68: 1932-1994.

10. Kornacki, J.L.; Gurtler, J. (2006). Incidence and control of Listeria in food processing facilities. In: Riemann, H.P., Cliver, D.O. (eds) Foodborne Infections and Intoxications. Academic Press, p. 681766.

11. Krämer, K.H.; Baumgart, J. (1993). Sliced frankfurter-type sausage: inhibiting Listeria monocytogenes by means of a modified atmosphere. Fleischwirtsch., 73: 1279-1280.

12. McCarthy, S.A. (1997). Incidence and survival of Listeria monocytogenes in ready-to-eat seafood products. J. Food Prot., 60: 372-376.

13. Pagotto, F.; Corneau, N.; Farber, J. (2006). Listeria monocytogenes infections. In: Riemann, H.P., Cliver, D.O. (eds) Foodborne Infections and Intoxications. Academic Press, p. 313-340.

14. Peeler, J.T.; Houghtby, G.A.; Rainosek, A.P. (1992). The most probable number technique. In: Vanderzant, C., Splittstoesser, D.F. Compendium of methods for the microbiological examination of foods. (pp. 105-120). Washington: APHA.

15. Rosso, L.; Bajard, S.; Flandrois, J.P.; Lahellec, C.; Fournaud, J.; Veit, P. (1996). Differential growth of Listeria monocytogenes at 4 and 8 degrees: consequences for the shelf life of chilled products. J. Food Prot., 59: 944-949.

16. Schmidt, U. (1995). Sliced, vacuum-packed frankfurter-type sausage: technological measures to inhibit the growth of listeriae. Fleischwirtsch., 75: 804-807.

17. Schmidt, U.; Kaya, M. (1990). Behaviour of L. monocytogenes in vacuum-packed sliced frankfurter-type sausage. Fleischwirtsch., 70: 1294-1295.

18. Swaminathan, B.; Cabanes, D.; Zhang, W.; Cossart. P. (2007). Listeria monocytogenes. In: Doyle, M.P., Beuchat, L.R. (eds) Food Microbiology: fundamental and frontiers. 3. ed. Washington, D.C.: ASM Press, p. 322-341. 